\title{
The possible roles for polyamines in the initiation process of SV40 DNA replication in vitro
}

\author{
DONG-GIL KIM ${ }^{1}$, JUAN DU ${ }^{1}$, CHUNHUI MIAO ${ }^{1}$, JEE H. JUNG ${ }^{3}$, SANG CHUL PARK ${ }^{4}$ and DONG-KYOO KIM ${ }^{1,2}$ \\ ${ }^{1}$ Department of Biomedicinal Chemistry, and Institute of Functional Materials, ${ }^{2}$ Biohealth Product Research Center, \\ Inje University, Kimhae 621-749; ${ }^{3}$ College of Pharmacy, Pusan National University, Busan 609-735; \\ ${ }^{4}$ Department of Biochemistry and Molecular Biology, The Aging and Apoptosis Research Center, \\ Seoul National University College of Medicine, Seoul 110-799, Korea
}

Received May 14, 2007; Accepted July 25, 2007

\begin{abstract}
The polyamines are aliphatic cations which are present in millimolar concentrations in all mammalian cells, and are required for optimal growth of almost all cell types. In this study, the roles of polyamines in DNA replication in vitro and the mechanism by which polyamines affected DNA replication were examined using simian virus 40 DNA replication system in vitro. We found that polyamines inhibited DNA replication, but it is not clear at which stage this occurs. Spermidine inhibited the DNA cleavage by topoisomerase I at $8.0 \mathrm{mM}$, but stimulated its activity at $1.0 \mathrm{mM}$. Spermine also inhibited its activity at $4.0 \mathrm{mM}$, but stimulated at $1.0 \mathrm{mM}$. The ssDNA binding activity of replication protein A was slightly affected by polyamines. Polyamines, especially spermine, also significantly reduced polymerase $\alpha$-primase activity at $133 \mu \mathrm{M}$. Taken together, we suggest that the major inhibition of SV40 DNA replication may be due to the inhibition of pol $\alpha$-primase activity, and possible roles for polyamines in the initiation process are discussed.
\end{abstract}

\section{Introduction}

The polyamines spermidine and spermine and their precursor diamine putrescine are aliphatic cations which are present in millimolar concentrations in all mammalian cells (1). They are aliphatic polycations which are positively charged at physiological $\mathrm{pH}$ and are among the most cationic small molecules within the cell (2). Unlike the point charges of $\mathrm{Mg}^{2+}$ and $\mathrm{Ca}^{2+}$, the charge is distributed along the flexible carbon chains which enable the polyamines uniquely to bridge critical distances and thus allow specific interactions with

Correspondence to: Dr Dong-Kyoo Kim, Biohealth Product Research Center, Inje University, Kimhae 621-749, Korea

E-mail: chemkdg@inje.ac.kr

Key words: polyamine, DNA replication, replication protein A, topoisomerase, DNA polymerase polyanionic macromolecules such as DNA (3). The most obvious specific characteristic of the polyamines is their polybasic character which gives them a much higher affinity for acidic constituents than that exhibited by $\mathrm{Na}^{+}, \mathrm{K}^{+}$, $\mathrm{Mg}^{2+}, \mathrm{Ca}^{2+}$, or monoamines; this polybasic character is most pronounced with spermine because of its four positive groups. The polyamines are required for optimal growth of almost all cell types and increased biosynthesis is necessary for the traverse of a cell through the cell cycle. In contrast, depletion of polyamine content through inhibition of biosynthesis or via mutation of the key enzymes involved in their production results in significant inhibition of cell growth (4).

The cellular DNA replication factors include two DNA polymerases, DNA polymerase $\alpha(\operatorname{pol} \alpha)$ and $\delta(\operatorname{pol} \delta)$ and a number of novel DNA replication proteins, including replication protein A (RPA), replication factor C (RF-C) and the proliferating cell nuclear antigen (PCNA) (5). The pol $\alpha$ primase complex is responsible for the synthesis of the first DNA segment, which could be considered the first lagging strand Okazaki fragment but is subsequently utilized as the primer for the initiation of leading strand synthesis by pol $\delta$ $(5,6)$. Pol $\delta$ is shown carrying out elongation of the leading daughter strand in the presence of RPA and in conjunction with the protein factors PCNA and activator 1 (A1), also identified as RF-C. RPA mediates the unwinding of SV40 origin-containing DNA in the presence of SV40 T-Ag and topoisomerase. The interaction of SV40 T-Ag with DNA pol $\alpha$ primase complex is required for the initiation of SV40 DNA replication (7-9). Once replication initiates, the elongation phase continues by DNA pol $\delta$.

Several studies have demonstrated that DNA synthesis is inhibited in cells depleted of polyamines $(2,10)$. The key enzyme in polyamine formation is ornithine decarboxylase, required for synthesis of putrescine, which serves as the precursor for the two higher polyamines, spermidine and spermine. The $\mathrm{CHO}$ P22 cells with no detectable ornithine decarboxylase activity grow well in the absence of serum if polyamines are available, but without added polyamines they gradually cease growing. DNA synthesis in CHO P22 cells and in primary human embryo lung fibroblasts both during polyamine starvation and under normal conditions have been studied. [ $\left.{ }^{32} \mathrm{P}\right]$ orthophosphate labeled two sizes of DNA, a low 
molecular weight DNA corresponding to a marker of $\sim 450 \mathrm{bp}$ and a high molecular weight DNA, were founded. The ${ }^{32} \mathrm{P}-$ label appeared first in the short DNA species. After a pulsechase the small size DNA gradually lost the radioactivity in normal cells, while the large DNA gained label, but in polyamine-starved cells the DNA fragments lost their label without incorporation of the radioactivity into the high molecular weight DNA. It is suggested that polyamines play an important role in the ligation of Okazaki fragments and the failure to ligate Okzaki fragments into long DNA chains might be the primary cause for the cessation of the cellular growth after polyamine depletion (10).

DNA pol $\alpha$-primase, on the lagging strand, synthesizes short RNA-primed DNA fragments in the presence of RPA. Joining of these Okazaki fragments to form a completed daughter strand requires the action of a $5^{\prime} \rightarrow 3^{\prime}$-exonuclease and RNase $\mathrm{H}$ to remove the RNA primers, filling in the gaps by a polymerase, and sealing the nicks by DNA ligase. In this study, the roles of polyamines in the DNA replication were examined using SV40 DNA replication system in vitro. We suggest that the major inhibition of SV40 DNA replication may be due to the inhibition of pol $\alpha$-primase activity, and possible roles for polyamines in initiation process are discussed.

\section{Materials and methods}

Proteins, cell extracts, and DNA. SV40 origin-containing circular duplex DNA (pUC-ori ${ }^{+}$), SV40 T-Ag, topo I, human DNA pol $\alpha$-primase, RPA, and HeLa extract were prepared as described previously $(11,12)$.

In vitro SV4O DNA replication assay. The reactions were carried out as described previously (7). In brief, the reaction mixtures $(40 \mu \mathrm{l})$ included $40 \mathrm{mM}$ creatine phosphate/di-Tris salt ( $\mathrm{pH} 7.7), 1 \mu \mathrm{g}$ of creatine kinase, $7 \mathrm{mM} \mathrm{MgCl}, 0.5 \mathrm{mM}$ DTT, 4 mM ATP, $200 \mu \mathrm{M}$ UTP, GTP, and CTP, $100 \mu \mathrm{M}$ dATP, dGTP, and dCTP, $25 \mu \mathrm{M}\left[{ }^{3} \mathrm{H}\right] \mathrm{dTTP}$ (300 cpm/pmol), $0.6 \mu \mathrm{g}$ of SV40 T-Ag, $0.23 \mu \mathrm{g}$ of pUC-ori ${ }^{+}$, HeLa extracts, and polyamines as indicated. The reactions ran at $37^{\circ} \mathrm{C}$ for $2 \mathrm{~h}$, after which the acid-insoluble radioactivity was measured. Replication products were analyzed using $\left[\alpha^{-32} \mathrm{P}\right] \mathrm{dATP}$ $(30,000 \mathrm{cpm} / \mathrm{pmol})$ instead of $\left[{ }^{3} \mathrm{H}\right] \mathrm{dTTP}$ in these reactions. Replication products in the reaction mixture were analyzed by electrophoretically separating the isolated DNA in a $1.0 \%$ agarose gel overnight at $42 \mathrm{~V}$. The gel was subsequently dried and exposed to X-ray film.

Topoisomerase assay. Topoisomerase activity was measured by the relaxation of superhelical plasmid DNA (13). The $20 \mu 1$ assay mixture contained $50 \mathrm{mM}$ Tris- $\mathrm{HCl}(\mathrm{pH} 7.5), 120 \mathrm{mM}$ $\mathrm{KCl}, 10 \mathrm{mM} \mathrm{MgCl}_{2}, 0.5 \mathrm{mM}$ DTT, $0.5 \mathrm{mM}$ EDTA, bovine serum albumin $(30 \mu \mathrm{g} / \mathrm{ml}), \operatorname{pSA}(20 \mu \mathrm{g} / \mathrm{ml})$, and various amount of the enzyme. After $30 \mathrm{~min}$ at $30^{\circ} \mathrm{C}$, the reactions were stopped by the addition of $5 \mu 1$ of $5 \% \mathrm{NaDodSO}_{4} / 25 \%$ (wt/vol) Ficoll 400 (Pharmacia) containing $0.25 \mathrm{mg}$ of bromophenol blue per $\mathrm{ml}$. The electrophoresis and photography were done as described. One unit of activity is the amount of topoisomerase that relaxes half of the superhelical plasmid DNA under these conditions.

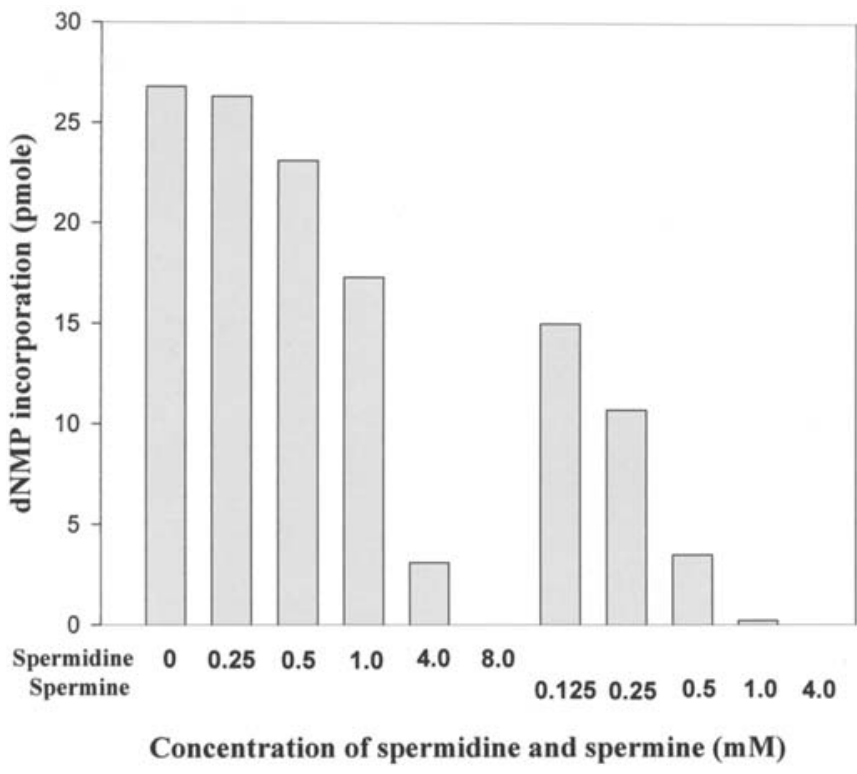

Figure 1. The effect of polyamines on SV40 DNA replication in vitro. Replication reaction comprised SV40 origin-containing DNA (pUC-ori ${ }^{+}$), SV40 T-Ag, HeLa cytosolic extract $(100 \mu \mathrm{g}),\left[{ }^{3} \mathrm{H}\right] \mathrm{dTTP}$, and the indicated amounts of polyamines. Reaction mixtures were incubated for $2 \mathrm{~h}$ at $37^{\circ} \mathrm{C}$, and the reaction products examined for acid-insoluble radioactivity.

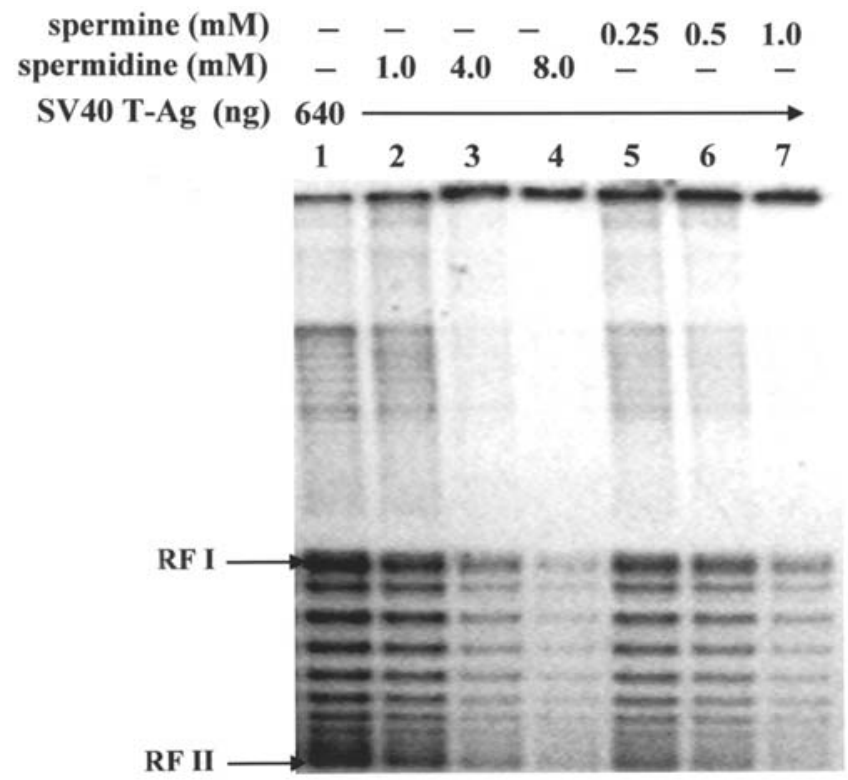

Figure 2. The effect of polyamines on SV40 DNA replication in vitro. Replication reaction comprised SV40 origin-containing DNA (pUC-ori ${ }^{+}$), SV40 T-Ag, HeLa cytosolic extract $(100 \mu \mathrm{g}),\left[\alpha^{-32} \mathrm{P}\right] \mathrm{dATP}$, and the indicated amounts of polyamines. Reaction mixtures were incubated for $2 \mathrm{~h}$ at $37^{\circ} \mathrm{C}$, and the reaction products were isolated and separated by $1 \%$ agarose gel electrophoresis (Tris-borate-EDTA buffer).

ssDNA binding assay. The ssDNA binding activity was measured according to the published procedures (14). The reaction mixtures $(20 \mu \mathrm{l})$ contained $50 \mathrm{mM}$ Hepes- $\mathrm{KOH}$ (pH 7.5), $150 \mathrm{mM} \mathrm{NaCl}, 1 \mathrm{mM} \mathrm{MgCl} 2,0.5 \mathrm{mM}$ DTT, $10 \%$ glycerol, $250 \mathrm{fmol}$ of 5'-32P-labeled $(\mathrm{dT})_{50}(1,200 \mathrm{cpm} / \mathrm{fmol})$, and the incubated amounts of RPA. After incubating the reaction mixtures for $15 \mathrm{~min}$ at $25^{\circ} \mathrm{C}$, the DNA-protein 
(A)

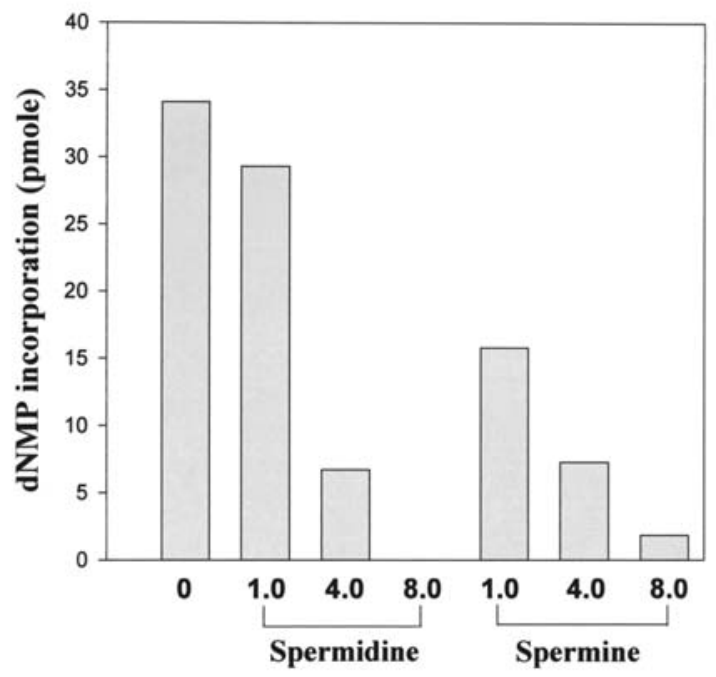

Concentration of spermidine and spermine $(\mathrm{mM})$

(B)

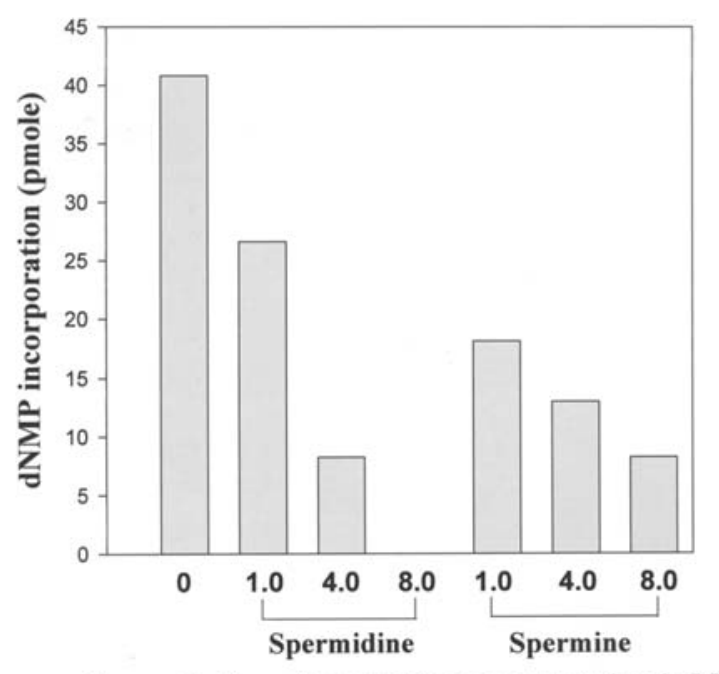

Concentration of spermidine and spermine $(\mathrm{mM})$

Figure 3. Polyamines inhibited the same initiation stage as elongation stage of SV40 DNA replication in vitro. Polyamines were added to reaction mixture before (A) or after (B) the preincubation in the presence of ATP at $37^{\circ} \mathrm{C}$ for $\left.30 \mathrm{~min} .{ }^{3} \mathrm{H}\right] \mathrm{dNTPs}$ were then added, and the mixture was incubated for $2 \mathrm{~h}$ at $37^{\circ} \mathrm{C}$, and the reaction products examined for acidinsoluble radioactivity. All the conditions were the same as those described in the legend for Fig. 2.

complexes were electrophoretically separated in a $5 \%$ polyacrylamide gel in $0.5 \mathrm{X}$ TBE buffer at $12 \mathrm{~V} / \mathrm{cm}$.

Polymerase assay. Polymerase activity was examined out as described previously (15) with the following modifications: the reaction mixtures $(30 \mu 1)$ included $40 \mathrm{mM}$ creatine phosphate/di-Tris salt, $\mathrm{pH} 7.7$, creatine kinase $1.0 \mu \mathrm{g}, 7 \mathrm{mM}$ $\mathrm{MgCl}_{2}, 1.0 \mathrm{mM}$ DTT, BSA $6 \mu \mathrm{g}, 4 \mathrm{mM}$ ATP, $\left[{ }^{3} \mathrm{H}\right]$-dTTP $33 \mu \mathrm{M}, 0.1 \mu \mathrm{g}$ poly $(\mathrm{dA})_{4500}:$ oligo $(\mathrm{dT})_{25}$, DNA pol $\alpha$-primase. The reactions ran at $37^{\circ} \mathrm{C}$ for $2 \mathrm{~h}$, after which the acid-insoluble radioactivity was measured.
(A)

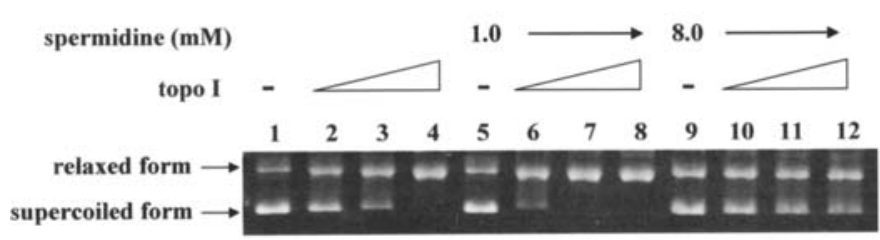

(B)

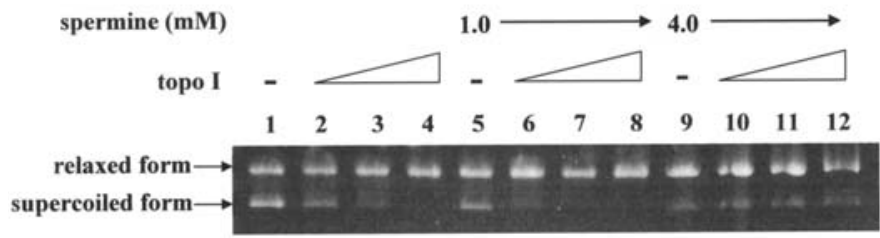

Figure 4. Polyamines inhibited topo I catalytic activity. Topoisomerase activity was measured by the relaxation of superhelical plasmid DNA. The assay mixture $(20 \mu \mathrm{l})$ contained pSA $(20 \mu \mathrm{g} / \mathrm{ml})$, topo I, and various amounts of the spermidine (A) and spermine (B). After $30 \mathrm{~min}$ at $30^{\circ} \mathrm{C}$, the reactions were stopped by the addition of $5 \mu 1$ of stop solution. The samples were then loaded onto the agarose gel $(0.8 \%)$ for electrophoresis and photography was done.

\section{Results}

Polyamines inhibited SV4O DNA replication in vitro. The roles of polyamines on DNA replication were examined using SV40 DNA replication system in vitro (Fig. 1). Polyamines showed inhibitory effects on DNA replication in SV40 DNA replication system. Spermidine showed inhibitory effect with $88 \%$ inhibition at $4.0 \mathrm{mM}$. Spermine showed inhibitory effect with $87 \%$ inhibition at $0.5 \mathrm{mM}$. Spermine showed a more inhibitory effect than spermidine. Agarose gel electrophoresis (Fig. 2) shows that the replication products include RF I, RF II (circular duplex DNA containing at least one single-strand break), intervening topoisomers, and discrete slower-migrating species. In addition, increasing polyamines quantitatively inhibited SV40 DNA replication. Three factors, SV40 T-Ag, RPA, and pol $\alpha$-primase complex, are essential for the initiation process. In the presence of topoisomerase, SV40 TAg will continue to unwind the DNA to form a highly unwound DNA. DNA synthesis with three factors and topoisomerase can be quite extensive. We questioned which stage of DNA replication is inhibited by polyamines.

Which stage of DNA replication was inhibited by polyamines? We examined whether the inhibitory effect of polyamines on SV40 DNA replication in vitro occurs at the level of initiation or elongation. Formation of a DNA-protein complex is a prerequisite for initiation of SV40 DNA replication. This complex is formed in the absence of dNTPs at $37^{\circ} \mathrm{C}$ and is dependent on the replication origin, SV40 T-Ag, ATP, and host proteins. Subsequent DNA synthesis in the presence of dNTPs occurs at either $25^{\circ} \mathrm{C}$ or $37^{\circ} \mathrm{C}$. Under standard reaction conditions, DNA replication displays biphasic kinetics. During the first phase, which lasts $\sim 10-20 \mathrm{~min}$, minimal or no DNA synthesis is observed. During the second phase, the rate of DNA synthesis increases rapidly to a relatively constant level that is maintained for at least $2 \mathrm{~h}$. 
(A)
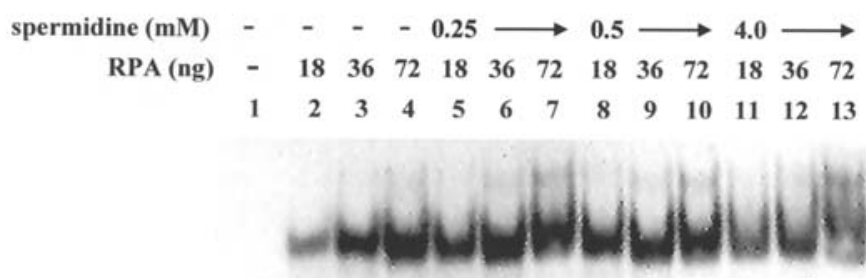

(B)

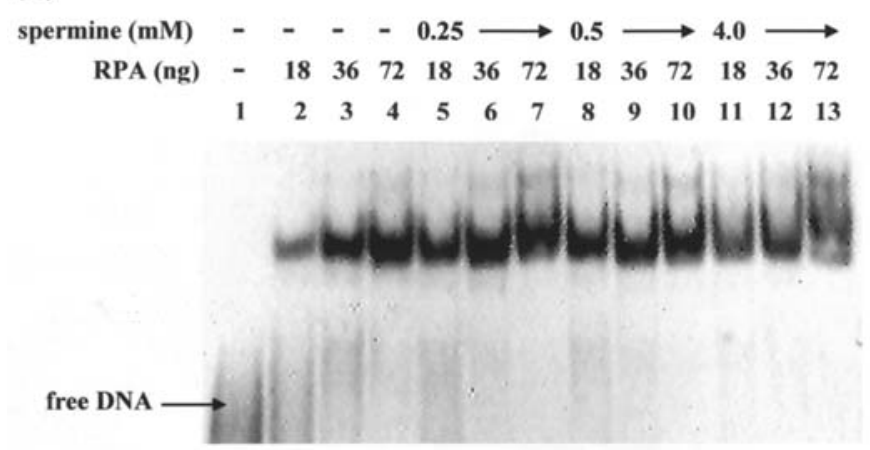

Figure 5. The effect of polyamines on RPA's ssDNA binding activity. Indicated amounts of either human RPA, or a mixture of both RPA and spermidine (A) and spermine (B) were combined with ${ }^{32} \mathrm{P}$-labeled (dT) $)_{50}$ and incubated at $25^{\circ} \mathrm{C}$ for $15 \mathrm{~min}$. The protein-DNA complexes were then separated from unbound DNA by $5 \%$ polyacrylamide (acrylamide : bisacrylamide $=$ 29:1) gel electrophoresis.

The initial lag in DNA synthesis can be eliminated if the complete reaction mixture is preincubated at $37^{\circ} \mathrm{C}$ in the absence of deoxynucleoside triphosphates. As shown in Fig. 3A and B, in the presence of polyamines, the replication activities were inhibited if added to reaction mixture before the preincubation in the presence of ATP (Fig. 3A), and also inhibited if added after the preincubation (Fig. 3B). Therefore, it is possible that polyamines may inhibit the initiation or elongation stage of DNA replication at nearly the same degree.

Polyamines inhibited topoisomerase I activity. We showed that it is not clear at which stage the polyamine inhibition occurred. Based on their properties, we suggest that polyamines might inhibit either an origin-binding protein or some other proteins required to establish a replication fork during the initiation reaction. To address this possibility, we asked whether polyamines inhibit topo I activity. By forming transient DNA single-strand breaks and acting as DNA strand transferase, topo I plays key roles in DNA replication, transcription, and recombination. The inhibitory effects of polyamines on the catalytic activity of topo I are shown in Fig. 4A and B. The plasmid DNA was in the superhelical form (lane 1), and topo I relaxed the supercoiled DNA (lane 2). Spermidine inhibited the DNA cleavage by topo I at $8.0 \mathrm{mM}$, but stimulated its activity at $1.0 \mathrm{mM}$. Spermine also inhibited topo I activity at $4.0 \mathrm{mM}$, but stimulated at $1.0 \mathrm{mM}$.
(A)

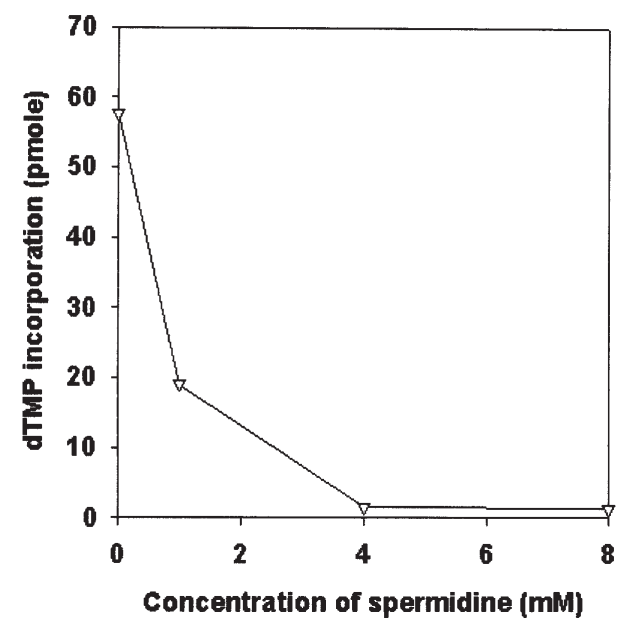

(B)

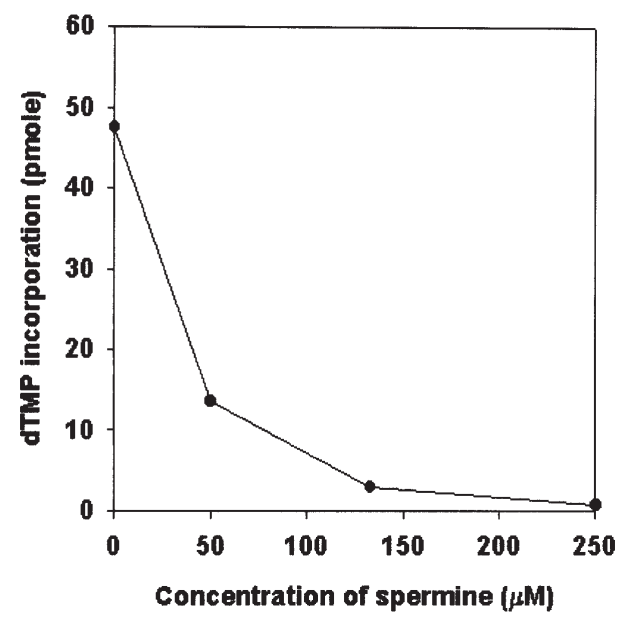

Figure 6. The effect of polyamines on pol $\alpha$-primase activity. (A) Indicated amounts of spermidine were added to the reaction mixture. (B) Indicated amounts of spermine were added to the reaction mixture, which included 0.1 unit of human pol $\alpha$-primase complex, $4 \mathrm{mM} \mathrm{ATP,} 1 \mathrm{mM}\left[{ }^{3} \mathrm{H}\right] \mathrm{dTTP}$, and $0.1 \mu \mathrm{g}$ of poly $(\mathrm{dA})_{4500}$ :oligo(dT) ${ }_{12-18}$. Incubation ran at $37^{\circ} \mathrm{C}$ for $30 \mathrm{~min}$, followed by measurement of acid-insoluble radioactivity.

The activity of RPA was slightly affected by polyamines. In replication, RPA mediates unwinding of SV40 origincontaining DNA in the presence of SV40 T-Ag and topoisomerase. It interacts with SV40 T-Ag and the DNA pol $\alpha$-primase complex, which is necessary for the initiation of SV40 DNA replication. We examined whether polyamines affect ssDNA-binding activity of RPA. As shown in Fig. 5A and B, RPA formed stable complexes with oligo $(\mathrm{dT})_{50}$, which appeared as two distinct bands in the polyacrylamide gel. The ssDNA binding activity of RPA was slightly affected by polyamines.

Polyamines significantly inhibited DNA pol $\alpha$-primase activity. As described above, DNA pol $\alpha$-primase complex is necessary for the initiation of SV40 DNA replication. To further investigate the inhibitory effect of polyamines in replication, we tested polyamines for inhibition of pol $\alpha$ activity to see whether their inhibitory effects on DNA replication correlate 
with pol $\alpha$ activity. As shown in Fig. 6A and B, spermidine completely inhibited pol $\alpha$-primase activity (Fig. 6A) at $4 \mathrm{mM}$, and spermine at $133 \mu \mathrm{M}$ (Fig. 6B). The above results indicate that major inhibition of SV40 DNA replication by polyamines may be due to the inhibition of pol $\alpha$-primase activity. Herein, we cannot rule out the possibility that polyamines inhibit the activity of DNA pol $\alpha$, because it is essential for the elongation process.

\section{Discussion}

In Escherichia coli it has been suggested that polyamines may function in an unwinding protein and interact directly with the DNA (16). Polyamines can influence the binding of the pol $\alpha$ to the 3'-hydroxyl primer in order to decrease the reaction velocity. Polyamine has also been shown to increase the rate of movement of the replication fork and hence increase the rate of chain elongation in a polyamine-deficient strain of E. coli.

The exact mode of action of the polyamines on DNA replication is unclear. In this study, the role of polyamines in DNA replication was examined using the SV40 DNA replication system in vitro. We found that polyamines showed inhibitory effect on DNA replication in vitro. However, it is not clear at which stage of DNA replication the inhibition occurs.

In SV40 DNA replication, three factors, SV40 T-Ag, RPA, and pol $\alpha$-primase complex, are essential for the initiation process $(17,18)$. In the presence of topoisomerase, SV40 T-Ag will continue to unwind the DNA to form a highly unwound DNA (19). DNA synthesis with three factors and topo-isomerase can be quite extensive (20). We have suggested that polyamines might interfere with some molecules that are required to establish replication forks during the initiation reaction (21). To address this possibility, we asked whether polyamines inhibit topo I, the ssDNA binding activity of RPA, and pol $\alpha$-primase activity. Polyamines inhibited the DNA cleavage by topo I. Spermidine inhibited the DNA cleavage by topo I at $8.0 \mathrm{mM}$, but stimulated its activity at $1.0 \mathrm{mM}$. Spermine also showed inhibitory effect on topo I activity at $4.0 \mathrm{mM}$, but stimulation at $1.0 \mathrm{mM}$. Our results suggest that the ratio of DNA to polyamine may be an important factor in determining whether the topo I reaction is stimulated or inhibited.

The ssDNA binding activity of RPA was slightly affected by polyamines. We thought that the inhibitory effects of poly-amines in DNA replication might not correlate with the activity of RPA. On the other hand, spermidine, at $4 \mathrm{mM}$, reduced pol $\alpha$-primase activity, and spermine significantly reduced at $133 \mu \mathrm{M}$. The above results indicate that major inhibition of SV40 DNA replication by polyamines may be due to the inhibition of pol $\alpha$-primase activity. However, we cannot rule out the possibility that polyamines inhibit the activity of DNA pol $\delta$, because it is essential for the elongation process.

Based on their properties, we suggest that polyamines inhibit some molecules that are required to establish replication forks during the initiation reaction or inhibit synthesis of Okazaki DNA fragment through inhibition of pol $\alpha$-primase activity.

\section{Acknowledgements}

This study was supported by the 2004 Inje University research grant.

\section{References}

1. Sarhan S and Seiler N: On the subcellular localization of the polyamines. Biol Chem Hoppe-Seyler 370: 1279-1284, 1989.

2. Tabor CW and Tabor H: Polyamines. Ann Rev Biochem 53: 749-790, 1984.

3. Wallace HM: Polyamines: specific metabolic regulators or multifunctional polycations? Biochem Soc Trans 20: 569-571, 1998.

4. Pohjanpelto P and Holtta E: Phosphorylation of Okazaki-like DNA fragments in mammalian cells and role of polyamines in the processing of this DNA. EMBO J 15: 1193-1200, 1996.

5. Hurwitz J, Dean FB, Kwong AD and Lee SH: The in vitro replication of DNA containing the SV40 origin. J Biol Chem 265: 18043-18046, 1990.

6. Weinberg DH and Kelly TJ: Requirement for two DNA polymerase in the replication of simian virus 40 DNA in vitro. Proc Natl Acad Sci USA 86: 9742-9746, 1989.

7. Lee SH, Eki Y and Hurwitz J: Synthesis of DNA containing the simian virus 40 origin of replication by the combined action of DNA polymerase $\alpha$ and $\delta$. Proc Natl Acad Sci USA 86: 7361-7365, 1989

8. Sengupta DJ and Borowiec JA: Strand-specific recognition of a synthetic DNA replication fork by the SV40 large tumor antigen. Science 256: 1656-1661, 1992.

9. Murakami Y and Hurwitz J: Functional interactions between SV40 T antigen and other replication proteins at the replication fork. J Biol Chem 268: 11008-11017, 1993.

10. Pohjanpelto P: Putrescine shortens the S-period in human fibroblasts. Biomedicine 23: 350-352, 1975.

11. Lee SH, Pan ZQ, Kwong D, Burgers PM and Hurwitz J: Synthesis of DNA by DNA polymerase epsilon in vitro. J Biol Chem 266: 22707-22717, 1991.

12. Kim DK, Stigger E and Lee SH: Role of the 70-kDa subunit of human replication protein A. J Biol Chem 271: 15124-15129, 1995.

13. Lin LF and Miller KG: Eukaryotic DNA topoisomerases: two forms of type I DNA topoisomerases from HeLa cell nuclei. Proc Natl Acad Sci USA 78: 3487-3491, 1981.

14. Lee SH and Hurwitz J: Mechanism of elongation of primed DNA by DNA polymerase $\delta$, proliferating cell nuclear antigen, and activator I. Proc Natl Acad Sci USA 87: 5672-5676, 1990.

15. Kenny MK, Lee SH and Hurwitz J: Multiple functions of human single-stranded-DNA binding protein in simian virus 40 DNA replication: single-strand stabilization and stimulation of DNA polymerase $\alpha$ and $\delta$. Proc Natl Acad Sci USA 86: 9757-9761, 1989.

16. Wallace HM, Duff PM, Pearson CK and Keir HM: The effect of polyamines on DNA synthesis in vitro. Biochim Biophys Acta 652: 354-357, 1981 .

17. Matsumoto T, Eki T and Hurwitz J: Studies on the initiation and elongation reactions in the simian virus 40 DNA replication system. Proc Natl Acad Sci USA 87: 9712-9716, 1990.

18. Blackwell LJ and Borowiec JA: Human replication protein A binds single-stranded DNA in two distinct complexes. Mol Cell Biol 14: 3993-4001, 1994.

19. Wold MS and Kelly TJ: Purification and characterization of replication protein $\mathrm{A}$, a cellular protein required for in vitro replication of simian virus 40 DNA. Proc Natl Acad Sci USA 85: 2523-2527, 1988.

20. Ishimi Y, Claude A, Bullock P and Hurwitz J: Complete enzymatic synthesis of DNA containing the SV40 origin of replication. J Biol Chem 263: 19723-19733, 1988.

21. Kim DK, Baek JH, Kang CM, Sung JW, Lee BE, Chung HY, Kim ND, Lee SH and Kim KW: Apoptotic activity of UA may correlate with the inhibition of initiation of DNA replication. Int J Cancer 87: 629-636, 2000. 